\title{
Impact of Drainage Effluents on The Water Quality of Abu-Qir Bay, Alexandria, Egypt
}

\author{
Hoda A.E. Hemaida*
}

\begin{abstract}
Abu-Qir Bay, a semi-enclosed heavily polluted Mediterranean basin in Egypt, is receiving huge amounts of untreated sewage, industrial, and agricultural waste waters via three land-based sources: Tabia pumping station [TPS], Outlet of lake Edku [Boughaz El-Maadiya], and Rosseta mouth of River Nile. In order to mitigate and control the impact of pollution on coastal and marine resources, it is essential that the type and load of pollutants be identified. So water samples were collected from sixteen stations covering Abu-Qir Bay, seven stations covering Lake Edku, one sample from El-Ammia Drain [TPS], and eight samples from the drains affected or entering lake Edku during April and May 2005. The hydrochemical parameters, i.e., water temperature, chlorosity, salinity, dissolved oxygen $\mathrm{pH}$, total suspended matter, oxidizable organic matter, calcium, and magnesium as well as nutrient salts: the nitrogen forms [ammonium, nitrite, and nitrate], the reactive phosphate and reactive silicate were investigated.
\end{abstract}

\section{INTRODUCTON}

Abu-Qir Bay has a shoreline of about 50 $\mathrm{km}$ west of the Nile Delta. The bay lies on the south Levant basin of the Mediterranean Sea. The bay was known to be one of the most important fishery grounds in Egypt. Now, the bay daily receives continuous discharges from three land-based sources mainly agricultural drainage waters from Lake Edku and industrial effluents from Tabia drain. Moreover, sewage waste enters the Bay. This work aimed at studying the impact of these drainage effluents on the water quality of Abu-Qir Bay. So, the water chemistry of Abu-Qir Bay, Lake
Edku and drains subjected to the bay [TPS], and the lake was studied. Intensive attention was paid to investigate physicochemical characteristics of Abu- Qir Bay. ${ }^{1-12}$

\section{Study area:}

Abu-Qir Bay is a shallow bay which lies between $31.27-31.47^{\circ} \mathrm{N}$ and $30.7-30.33^{\circ} \mathrm{E}$ east of Alexandria [Fig.1], with an average depth less than $10 \mathrm{~m}$ and water volume of 4.3 $X 10^{9} \mathrm{~m}^{3}$. The area of the bay is about 430 $\mathrm{km}^{2}$. It receives a substantial load of pollution from the various land-based activities surrounding it and through River Nile drainage

\footnotetext{
${ }^{*}$ National Institute of Oceanography and Fisheries, Alexandria, Egypt.
} 
and Lake Edku. The pollution input in the bay from these two main sources is as follows:

a) El-Tabia Pumping Station [TPS], in the south- east part of the bay with about $2 \times 10^{6} \mathrm{~m}^{3}$ day $^{-1}$ discharging capacity. It was estimated that about $730 \times 10^{6} \mathrm{~m}^{3}$ of waste waters are discharged annually through this point source, in channel [EIAmmia] of $200 \mathrm{~m}$ length. These wastes are mainly industrial, with some agricultural and domestic contribution.

b) Lake Edku $\left[31.27^{\circ} \mathrm{N}\right.$ and $\left.30.15^{\circ} \mathrm{E}\right]$. It covers an area of $126 \mathrm{~km}^{2}$ with a mean depth of $1 \mathrm{~m}$ [Fig.2]. This coastal lagoon is almost an agricultural drain. Through its connection with the bay [Boughaz ElMaadiya] about $390 \times 10^{6} \mathrm{~m}^{3}$ of agricultural waste. Water is charged annually into Abu-Qir Bay. Two main drains discharge their water into Lake Edku. The first drain namely Kom Belag receives its water from three sub drains; Bosily, Edku, and El-Khairy where they are connected at about $3 \mathrm{~km}$ to the east of the lake. The second main drain is Bersik
Drain which outlets its water at the southern central part of the lake.

\section{MATERIAL AND METHODS:}

During spring 2005, four field trips were performed. A total of 16 stations allover AbuQir Bay were selected to represent different locations situated under the direct effect of land-based sources and some other sites [Fig.1]. Seven sampling stations were selected at lake Edku and eight ones from the drains affecting the lake [Fig.2]. Moreover, one water sample was collected from El-Ammia Drain representing the effluent of TPS.

Temperature, total dissolved solids and $\mathrm{PH}$ were determined in Situ at time of sampling using a portable microprocessor based $\mathrm{pH}$, conductivity, and temperature meter model M90. Salinity $[S \%$ was calculated from the electrical conductivity of samples measured by a Beckman Salinometer. Chlorosity was determined by Mohr's titration method as described by

Vogel. ${ }^{13}$ Dissolved oxygen [DO] was analyzed according to the modified Winkler method. ${ }^{14}$ Oxidizable organic matter [OOM] 
according to Calberg method. ${ }^{15}$ Calcium and magnesium were determined titrimetrically according to the method of Heron and Mackereth. ${ }^{16}$ using EDTA standard solution. Nutrients [nitrite, nitrate, ammonia, phosphate, and silicate] were analyzed spectrophotometrically according to recent oceanographic methods described by Grasshoff [1976] ${ }^{14}$ using a Shimadzue double beam spectrophotometer.

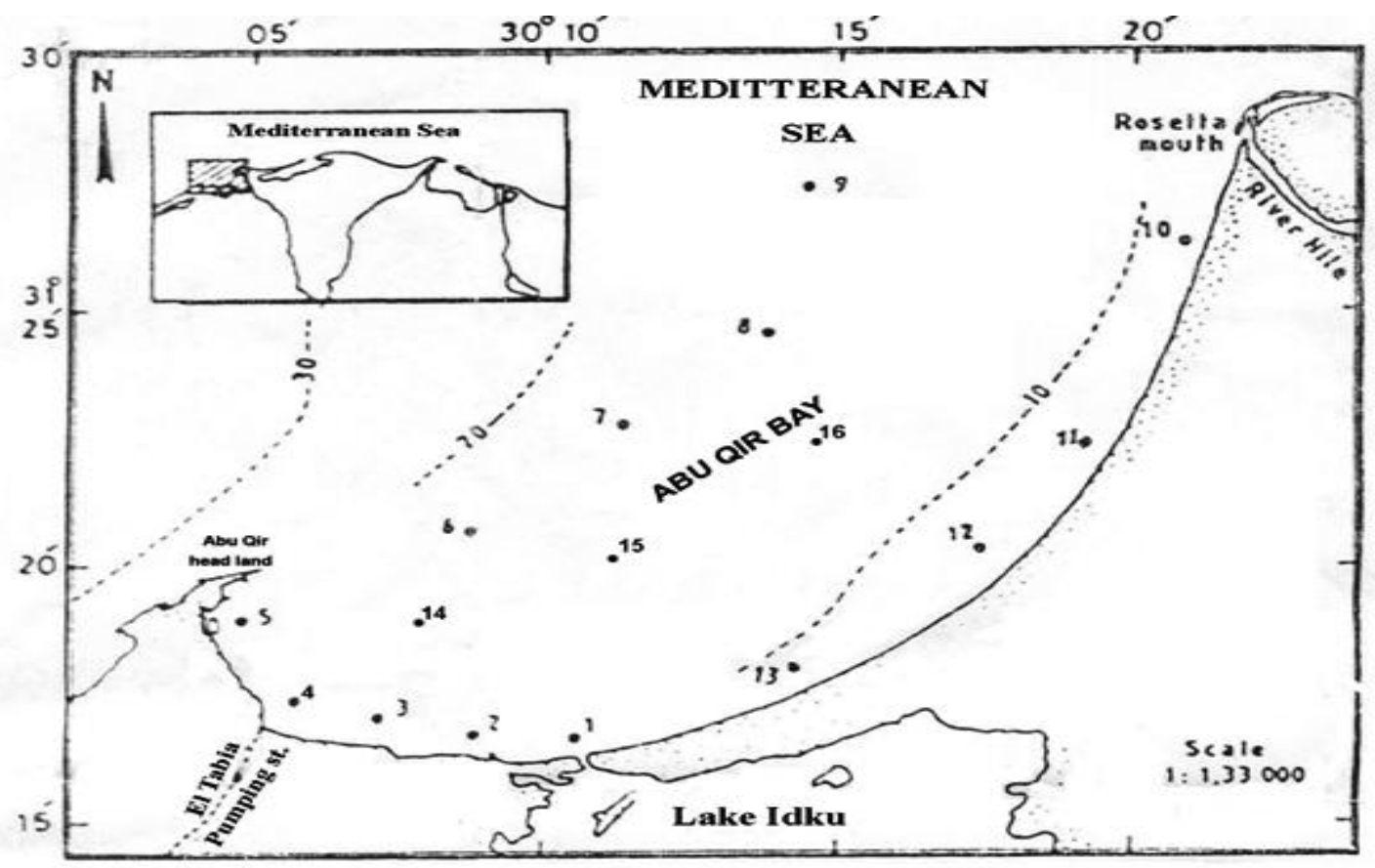

Figure 1: The study area; the sampling stations at Abu-Qir Bay and El-Tabia Pumping Station. 


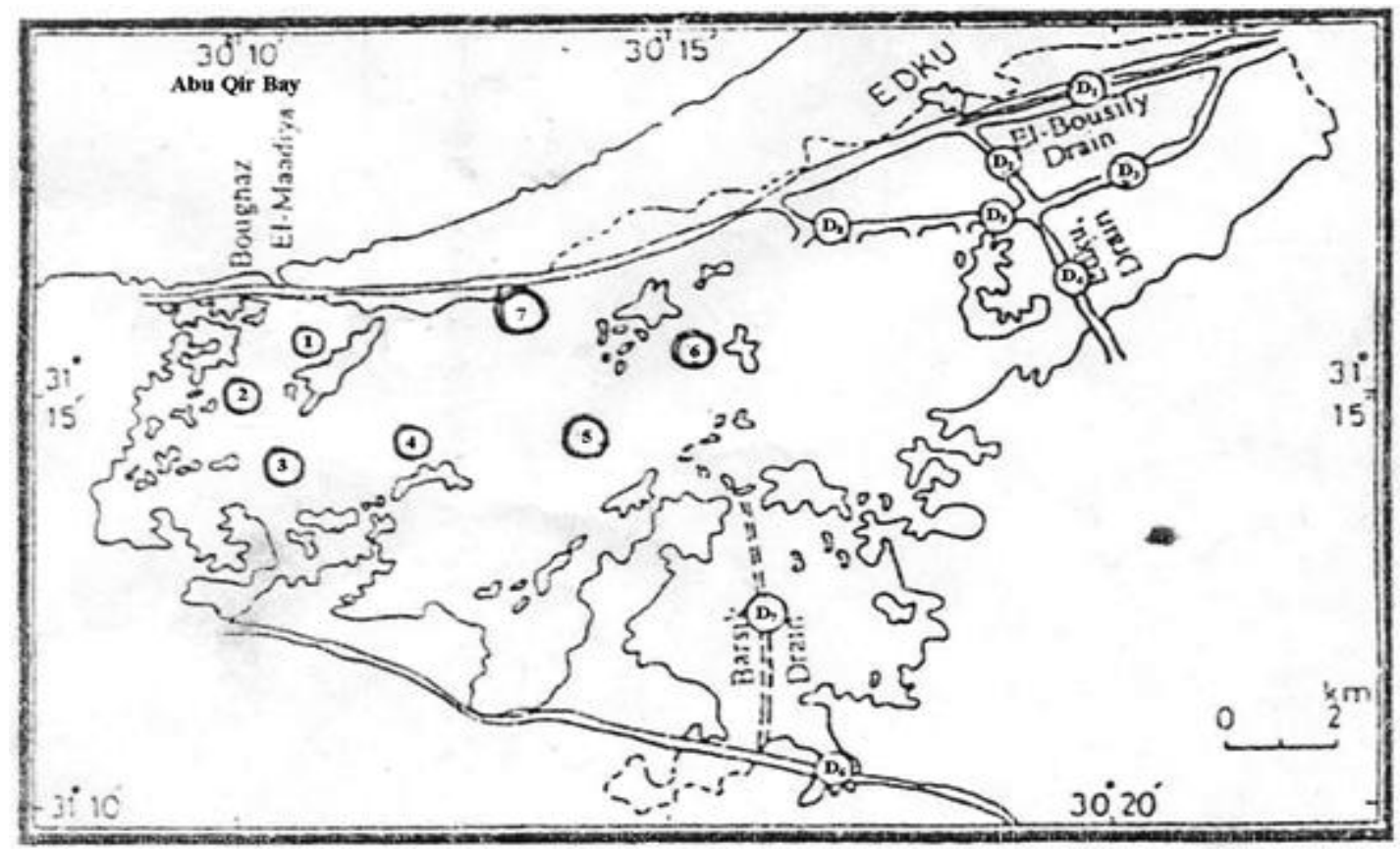

Figure 2: The location map of sampling stations in Lake Edku and its Drains.

\section{RESULTS AND DISCUSSION:}

The results of the studied variables in this paper are recorded in tables 1 and 2 and represented graphically in figures 3-7.

I- Physico- chemical characteristics:

The water temperature at Abu-Qir Bay and Lake Edku exhibited higher values than those of the connected drains. However, the higher temperature values, reaching the maximum of $29.5{ }^{\circ} \mathrm{C}$, were observed at the bay. In the drains waters of Lake Edku, the temperature values ranged between 17.0 and $18.0^{\circ} \mathrm{C}$, while El-Ammia Drain water recorded $19.5^{\circ} \mathrm{C}$.

The present data display that all the $\mathrm{pH}$ values were on the slight alkaline side and lower than that of the open sea. The $\mathrm{pH}$ values of Abu-Qir Bay [ranged from 7.25-8.35] were slightly lower than that recorded for water of Lake Edku [8.1-8.5] and the drains [7.77-9.2].

Salinity and chorosity showed the some trend at Abu-Qir Bay, Lake Edku, and their related drains [Figs. 3, 6, and 7]. El-Ammia Drain [TPS] exhibited of course an 
extraordinary low absolute salinity [1.56\%o] and chlorosity [0.48 g/L]. At Abu-Qir Bay, salinity distributions [Fig. 3] reflect the influence of the drainage outflows mainly in the northwestern part of the bay [sts. 1, 3, and 4] which recorded the lowest absolute salinity values [9.08, 14.46, and 19.40\%, consequently the lowest chlorosity $[1.13,3.78$, and $4.91 \mathrm{~g} / \mathrm{L}$ ] resulting from the extreme freshwater discharges at these stations. The highest absolute salinity values were recorded at the offshore stations of the bay [sts. 6-9] due to the mixing with Mediterranean coastal waters. It is clear from salinity distribution of the bay waters that salinity levels [consequently chlorosity] were dependent on the amount of the discharged fresh water derived from the effluents of land-based sources. Lake Edku water exhibited low TDS values ranging between $0.77 \mathrm{~g} / \mathrm{L}$ at st. 7 and $1.54 \mathrm{~g} / \mathrm{L}$ at st.3. However, its connected drains recorded little higher values ranged from 1.16 $\mathrm{g} / \mathrm{L}$ at $\mathrm{D}_{5}$ to $3.72 \mathrm{~g} / \mathrm{L}$ at $\mathrm{D}_{7}$.

Dissolved oxygen is considered as one of the best indicators of aquatic health. DO measurements clearly indicated that, the present load of organic matter and nutrients of the drains and Lake Edku waters which also reached Abu-Qir Bay are below the level that can bring the oxygen deficiency. Only complete depletion of oxygen was observed for one time at station 4 in Abu-Qir Bay during the present study. Nessim et al., 2005 recorded at Abu-Qir Bay [1.17-5.14 ml/L] for DO ${ }^{17}$, which is near to the DO recorded in this study $[0.00-9.14 \mathrm{ml} / \mathrm{L}]$. However, the study area appeared to be well oxygenated, DO concentrations in Lake Edku ranged between $7.05 \mathrm{mg} / \mathrm{L}$ and $19.69 \mathrm{mg} / \mathrm{L}$, in its related drains ranged between $7.64 \mathrm{mg} / \mathrm{L}$ and $14.11 \mathrm{mg} / \mathrm{L}$, and El-Ammia Drain recorded the minimum DO value $[3.09 \mathrm{mg} / \mathrm{L}]$.

The spatial variation in OOM content at Abu-Qir Bay is mainly due to the quality and quantity of the discharged drainage water in Lake Edku consequently enter the bay through Boughaz El-Maadiya and from TPS which is loaded with organic and inorganic pollutants. Table 2 shows that no pronounced difference in the OOM contents of Lake Edku and its 
related drains. It ranged between 0.13 and $7.98 \mathrm{mgO}_{2} / \mathrm{L}$ in the lake water, while in the drains water ranged between 0.46 and 8.79 $\mathrm{mgO}_{2} /$ L. At Abu-Qir Bay, OOM content ranged between 0.71 and $15.94 \mathrm{mgO}_{2} / \mathrm{L}$. It is quite clear that high OOM values were recorded in shore area [sts. 2, 3, and 13] which are near to the discharging of drainage waters from the inlet of Lake Edku and TPS. Station 10 attained also high OOM content $\left[7.90 \mathrm{mgO}_{2} / \mathrm{L}\right]$ possibly due to the influence of the Nile River discharging into the bay area. It is noticeable that during the present study, higher OOM values were recorded in the central basin of the bay represented by stations 14,15 , and 16. These results clearly demonstrate the influence of the water circulation regimes in the bay in this season. ${ }^{18}$ In general, it can be assumed that the organic matter of the bay water is mainly allochtonous rather than autochtonous produced as a result of biological productivity of the bay.

The calcium content reflect the quality of the drainage network effluents, of which ElAmmia Drain recorded $58.6 \mathrm{mg} / \mathrm{L}$, while Edku
Drains exhibited extraordinary low calcium values ranged from $15.26 \mathrm{mg} / \mathrm{L}$ at $\mathrm{D}_{4}$ to 27.36 $\mathrm{mg} / \mathrm{L}$ at $\mathrm{D}_{3}$ and $\mathrm{D}_{7}$. Lake Edku showed relatively little higher level of calcium, if it compared with that recorded at its related drains, ranged from $19.54 \mathrm{mg} / \mathrm{L}$ at stations 1 , 2, and 6 to $70.34 \mathrm{mg} / \mathrm{L}$ at station 7 [Table 2]. The hydrography of Abu-Qir Bay shows that the dispersal pattern of the land-based materials is governed by its water stratification and circulation regimes, which in turn depend on the seasonal variation in discharged fresh waters coming either from Lake Edku or through the Rosseta Nile branch. ${ }^{19}$ Inshore stations 1, 2, 3, and 4, to the left of Bougaz ElMaadiya, recorded the lowest calcium concentrations while the offshore stations 5-9 recorded the highest concentrations [Table 1]. The minimum value of $46.89 \mathrm{mg} / \mathrm{L}$ was recorded at stations 1 and 4 , while the maximum value of $562.72 \mathrm{mg} / \mathrm{L}$ was recorded at station 7 .

Magnesium content attained the same trend of calcium, where El-Ammia Drain, Lake Edku, and its related drains exhibited 
extraordinary low values. El-Ammia Drain recorded $35.5 \mathrm{mg} / \mathrm{L}$, Lake Edku attained low values ranged from $43.84 \mathrm{mg} / \mathrm{L}$ at stations 3 and 4 to $75.83 \mathrm{mg} / \mathrm{L}$ at station 2. However, the related lake drains recorded near values ranged from $29.62 \mathrm{mg} / \mathrm{L}$ at $D_{5}$ to $71.09 \mathrm{mg} / \mathrm{L}$ at $D_{3}$ and $D_{7}$ [Table 2]. At Abu-Qir Bay, inshore stations 1-4 recorded also, like calcium, the lowest magnesium concentrations. However, the offshore stations 5-9 recorded the highest concentrations. The minimum value of 90.05 $\mathrm{mg} / \mathrm{L}$ was recorded at station 1 and the maximum value of $1767.82 \mathrm{mg} / \mathrm{L}$ was record at station 7 . The strong relationship between $\mathrm{Ca}$ and $\mathrm{Mg}$ in the water of Abu-Qir Bay is clearly demonstrated [Fig. 5].

\section{Nutrient Salts}

The studied nutrients in Abu-Qir Bay, Lake Edku, and their related drains are: nitrites, nitrates, ammonia, phosphates, and silicated. The data obtained in this study are recorded in Tables 1 and 2 and represented graphically in figures 4 and 8 . Human-induced eutrophication occurs due to nutrient loading from point sources [outfall discharges of industrial plants and sewage treatment works] and of human-influenced 'diffuse sources' [run off from any but specially an agricultural catchment]. Point sources discharges are usually relatively controllable. ${ }^{20}$ The distribution of nutrients in Lake Edku showed that nutrient enrichment of the lake and its drains has always occurred. The obtained data showed that no distinct differences between them in the nitrite, nitrate, and silicate concentrations [Table 2]. The absolute values of nitrite ranged from $0.93-29.70 \mu \mathrm{M}$ in stations 2 and 7 of the lake water, respectively. While, the drains recorded little higher values ranged between 6.23-24.18 $\mu \mathrm{M}$ at $D_{6}$ and $D_{2}$, respectively. The minimum absolute value of nitrate [2.63 $\mu \mathrm{M}]$ was recorded at station 1 of the lake water, while the maximum value of $147.06 \mu \mathrm{M}$ was observed at station 7 . The related drains recorded near nitrate levels to the lake water ranging from 22.04-105.76 $\mu \mathrm{M}$ at $D_{6}$ and $D_{2}$, respectively. The reactive silicate of the lake water ranged from $7.72-80.62 \mu \mathrm{M}$ at stations 2 
and 3 , respectively, while the drains water showed little higher values ranging from 40.62-120.92 at $D_{3}$ and $D_{7}$, respectively whereas higher ammonium and phosphate concentrations were recorded in the drains waters of Lake Edku than those in the lake water. The lake water showed the minimum absolute value of phosphate $[2.20 \mu \mathrm{M}]$ at station 2 , while the maximum value of $6.75 \mu \mathrm{M}$ was observed at station 4 . The reactive phosphate concentrations in the drains water ranged from $6.90-9.85 \mu \mathrm{M}$ at $D_{1}$ and $D_{5}$, respectively. Much higher concentrations of ammonium were observed in the drains water ranging from $38.5-116.5 \mu \mathrm{M}$ at $D_{7}$ and $D_{5}$, respectively. While, ammonium concentrations of the lake water ranged from 3.90-97.15 $\mu \mathrm{M}$, at stations 2 and 4 , respectively.

From the nutrient data sets at Abu-Qir Bay, it is obvious that significantly high nutrient concentrations were recorded to the left of Lake Edku inlet and near TPS, indicating the influence of the drainage water on Abu-Qir Bay ecosystem [Table 1]. It is noteworthy that during this study, the nutrient values measured at stations 7-11 were considerably decreased, when compared to those in the other sites [Table 1]. It seems that the flow rate of the River Nile was decreased during April and May 2005. El-Ammia Drain water recorded very high nutrient concentrations. The enhanced nutrient values at those stations coincided with the lowest salinity values [Table 1]. The high nutrient surface concentrations which were observed at the stations located near Boughaz El-Maadiya [1, 2, and 3] and in opposite to TPS [4 and 5] indicated a rather eutrophic environment which was contributed very close to the drains discharge. As mixing with offshore waters progressed at stations 6-9, nutrient levels decreased considerably. Stations 10-13, which are located to the right of Boughaz ElMaadiya, showed very low nutrient concentrations reflecting the mixing with Mediterranean coastal waters may be to the status of prevailing wind and current at the period of study. ${ }^{18}$

Generally, the obtained data in Tables 1 and 2 show that there has been a very high 
increase in nutrient concentrations in the matter and nutrients. According to Orive et al., drains water and consequently in its inputs 2002, the estuary may operate as source and and in Abu-Qir coastal area. The central zone as sink of organic matter and nutrients. ${ }^{20}$ of the bay appeared to be a sink to organic

Table [1]: Water characteristics of Abu-Qir Bay and El-Ammia Drain during spring 2005

\begin{tabular}{|c|c|c|c|c|c|c|c|c|c|c|c|c|}
\hline 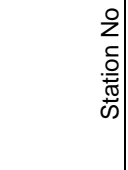 & 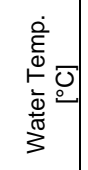 & 밍 & 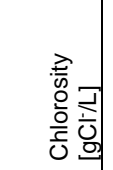 & 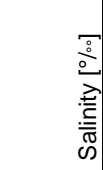 & 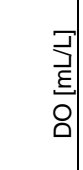 & 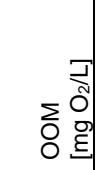 & $\begin{array}{l}\text { ] } \\
\text { है } \\
\text { है } \\
\pm \\
\pm \\
0\end{array}$ & 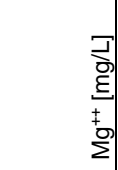 & 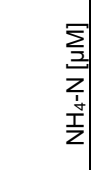 & 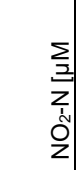 & $\begin{array}{l}\sum \\
\vdots \\
\vdots \\
0 \\
2\end{array}$ & $\sum_{\underline{2}}$ \\
\hline $1 \mathrm{~S}$ & 26 & 8.35 & 1.133 & 9.075 & 6.06 & 3.23 & 46.89 & 90.05 & 6.7 & 2.78 & 9.52 & 1.15 \\
\hline $2 S$ & 26.5 & 7.8 & 11.138 & 33.027 & 8.8 & 12.89 & 164.13 & 232.23 & 7.1 & 3.25 & 8.76 & 0.3 \\
\hline $3 S$ & 29.5 & 8.01 & 3.775 & 14.459 & 1.49 & 6.55 & 62.56 & 163.51 & 6.45 & 78.4 & 30.86 & 1.45 \\
\hline $4 S$ & 27.5 & 7.25 & 4.908 & 19.402 & 0 & 4.37 & 46.89 & 315.18 & 49.95 & 1.78 & 0.81 & 1.9 \\
\hline $5 S$ & 24 & 7.77 & 12.27 & 38.229 & 8.23 & 2.27 & 289.18 & 1210.94 & 3.05 & 0.48 & 16.58 & 0.75 \\
\hline $5 B$ & 22 & 7.7 & 12.648 & 38.676 & 5.03 & 10.12 & 320.44 & 1156.43 & 7.45 & 0.8 & 11.93 & 0.2 \\
\hline $6 S$ & 23.5 & 7.75 & 11.703 & 38.632 & 6.97 & 7.96 & 62.53 & 779.64 & 2.55 & 0.15 & 5.18 & 0.25 \\
\hline $6 B$ & 22 & 7.72 & 12.081 & 38.952 & 7.77 & 9.37 & 211.02 & 914.72 & 4.15 & 1.68 & 7.34 & 2.25 \\
\hline $7 S$ & 24.5 & 7.85 & 16.612 & 37.48 & 7.31 & 1.51 & 562.72 & 1767.82 & 4.75 & 0.08 & 3.16 & 0.5 \\
\hline $7 \mathrm{~B}$ & 20.5 & 7.62 & 23.785 & 38.968 & 6.74 & 0.71 & 531.46 & 1763.09 & 3.05 & 0.1 & 44.27 & 0.3 \\
\hline $8 S$ & 24 & 7.69 & 19.066 & 37.798 & 9.14 & 5.21 & 484.57 & 1649.34 & 2.95 & 0.03 & 0.81 & 0.35 \\
\hline $8 B$ & 21 & 7.66 & 12.648 & 39.032 & 5.37 & 2.81 & 508.01 & 1682.51 & 3.75 & 0.08 & 0.92 & 0.4 \\
\hline 9S & 24 & 7.72 & 15.479 & 38.352 & 6.63 & 2.26 & 461.12 & 1639.86 & 2.25 & 0.05 & 4.82 & 0.25 \\
\hline $9 \mathrm{~B}$ & 22 & 7.59 & 21.897 & 38.832 & 4.57 & 1.26 & 554.91 & 1535.59 & 4.2 & 0.2 & 0.76 & 0.45 \\
\hline $10 \mathrm{~S}$ & 24 & 7.67 & 22.275 & 38.528 & 5.26 & 9 & 312.62 & 1291.51 & 3.55 & 0.1 & 0.87 & 0.3 \\
\hline $11 \mathrm{~S}$ & 24 & 7.78 & 25.107 & 38.273 & 8.23 & 6.68 & 406.41 & 1720.43 & 3.85 & 0.05 & 2.69 & 0.4 \\
\hline $12 S$ & 24 & 7.76 & 13.78 & 38.364 & 6.4 & 6.72 & 468.94 & 1729.91 & 3.9 & 0.13 & 0.78 & 0.4 \\
\hline $13 S$ & 25.5 & 7.84 & 10.382 & 33.382 & 5.94 & 8.69 & 328.25 & 357.83 & 6.5 & 2.73 & 5.18 & 0.55 \\
\hline $14 \mathrm{~S}$ & 24 & 7.6 & 13.214 & 38.848 & 5.03 & 15.94 & 187.57 & 170.62 & 1.55 & 1.28 & 21.17 & 1.4 \\
\hline $14 \mathrm{~B}$ & 23 & 7.41 & 13.78 & 38.912 & 8.11 & 10.14 & 62.52 & 388.64 & 4.9 & 1.13 & 18.06 & 0.8 \\
\hline $15 \mathrm{~S}$ & 26 & 7.75 & 9.627 & 30.2 & 5.48 & 8.63 & 156.31 & 1137.47 & 6.1 & 3.33 & 27.47 & 1 \\
\hline $15 B$ & 23 & 7.69 & 11.893 & 38.544 & 5.94 & 7.41 & 171.94 & 1199.09 & 2.8 & 0.28 & 8.18 & 0.3 \\
\hline $16 \mathrm{~S}$ & 24.5 & 7.81 & 13.592 & 35.974 & 7.54 & 4.6 & 171.94 & 689.59 & 70.2 & 1.78 & 2.07 & 1.2 \\
\hline $16 \mathrm{~B}$ & 23 & 7.69 & 10.76 & 38.564 & 7.31 & 9.72 & 93.78 & 488.17 & 7.55 & 0.33 & 49.31 & 0.35 \\
\hline $\begin{array}{c}\text { Ammia } \\
\text { Drain }\end{array}$ & 19.5 & 8 & 0.48 & 1.56 & 3.09 & 5.88 & 58.6 & 35.5 & 126.5 & 10 & 20.16 & 13.2 \\
\hline
\end{tabular}


Table [2]: Surface water characteristics of Lake Edku and its connected Drains during spring 2005

\begin{tabular}{|c|c|c|c|c|c|c|c|c|c|c|c|c|c|c|c|}
\hline \multirow{2}{*}{ Variable } & \multicolumn{7}{|c|}{ Lake Edku } & \multicolumn{8}{|c|}{ Drain } \\
\hline & St.1 & St.2 & St.3 & St.4 & St. 5 & St. 6 & St.7 & D1 & D2 & D3 & D4 & D5 & D6 & D7 & D8 \\
\hline Temp $\left({ }^{\circ} \mathrm{C}\right)$ & 20.5 & 20.5 & 21 & 21.5 & 22 & 22 & 23 & 18 & 18 & 17 & 17 & 18 & ND & 18 & 18 \\
\hline $\mathrm{pH}$ & 8.02 & 8.02 & 8.1 & 8.22 & 8.2 & 8.3 & 8.5 & 7.8 & 7.88 & 7.92 & 8.22 & 9.2 & 8.04 & 8.6 & 8 \\
\hline TDS [g/L] & 1.3 & 1.5 & 1.5 & 0.8 & 0.88 & 1.4 & 0.8 & 1.7 & 1.73 & 2.85 & 1.35 & 1.2 & 2.3 & 3.7 & 1.8 \\
\hline $\begin{array}{l}\text { Chlorosity } \\
\mathrm{mgCl} / / \mathrm{l}\end{array}$ & 415.3 & 471.9 & 491 & 340 & 302 & 566 & ND & 376 & 359 & 736 & 283 & 227 & 509.7 & 717 & 396 \\
\hline DO [mg/L] & 12.2 & 12.34 & 7.5 & 19.7 & 7.05 & 8.8 & 9.6 & 7.8 & 7.64 & 8.08 & 7.64 & 7.4 & 8.23 & 8.2 & 14 \\
\hline $\begin{array}{c}\mathrm{OOM}[\mathrm{mg} \\
\left.\mathrm{O}_{2} / \mathrm{L}\right]\end{array}$ & 5.54 & 3.86 & 0.1 & 5.84 & 1.47 & 6.9 & 8 & 5.9 & 4.1 & 4.45 & 4.12 & 0.5 & 4.79 & 8.2 & 1.1 \\
\hline $\mathrm{Ca}^{++}[\mathrm{mg} / \mathrm{L}]$ & 19.54 & 19.54 & 27 & 27.4 & 23.5 & 20 & 70 & 25 & 21.5 & 27.4 & 5.26 & 23 & 25.4 & 27 & 23 \\
\hline $\begin{array}{c}\mathrm{Mg}^{++} \\
{[\mathrm{mg} / \mathrm{L}]}\end{array}$ & 63.98 & 75.83 & 44 & 43.8 & 45 & 45 & 64 & 38 & 39.1 & 71.1 & 32 & 30 & 63.98 & 71 & 49 \\
\hline $\begin{array}{c}\mathrm{NH}_{4}-\mathrm{N} \\
{[\mu \mathrm{M}]}\end{array}$ & 4.15 & 3.9 & 12 & 97.2 & 58.6 & 7 & 69 & 24 & 41 & 54.2 & 106 & 117 & 76.15 & 39 & 84 \\
\hline $\begin{array}{c}\mathrm{NO}_{2}-\mathrm{N} \\
{[\mu \mathrm{M}]}\end{array}$ & 1.03 & 0.93 & 7.6 & 14 & 8.6 & 5.3 & 30 & 13 & 24.2 & 13 & 7.8 & 6.8 & 6.23 & 14 & 13 \\
\hline $\begin{array}{c}\mathrm{NO}_{3}-\mathrm{N} \\
{[\mu \mathrm{M}]}\end{array}$ & 2.63 & 20.13 & 15 & 50.4 & 69.2 & 81 & 147 & 59 & 106 & 67.6 & 25.8 & 23 & 22.04 & 61 & 47 \\
\hline $\begin{array}{c}\mathrm{PO}_{4}-\mathrm{P} \\
{[\mu \mathrm{M}]}\end{array}$ & 2.7 & 2.2 & 5.6 & 6.75 & 5.5 & 5.3 & 4.2 & 6.9 & 6.95 & 8.35 & 9.65 & 9.9 & 8.8 & 7.4 & 9.1 \\
\hline $\begin{array}{c}\mathrm{SiO}_{4}-\mathrm{Si} \\
{[\mu \mathrm{M}]}\end{array}$ & 9.22 & 7.72 & 81 & 61.4 & 66.2 & 11 & 60 & 44 & 58.5 & 40.6 & 66.9 & 60 & 104.6 & 121 & 85 \\
\hline
\end{tabular}

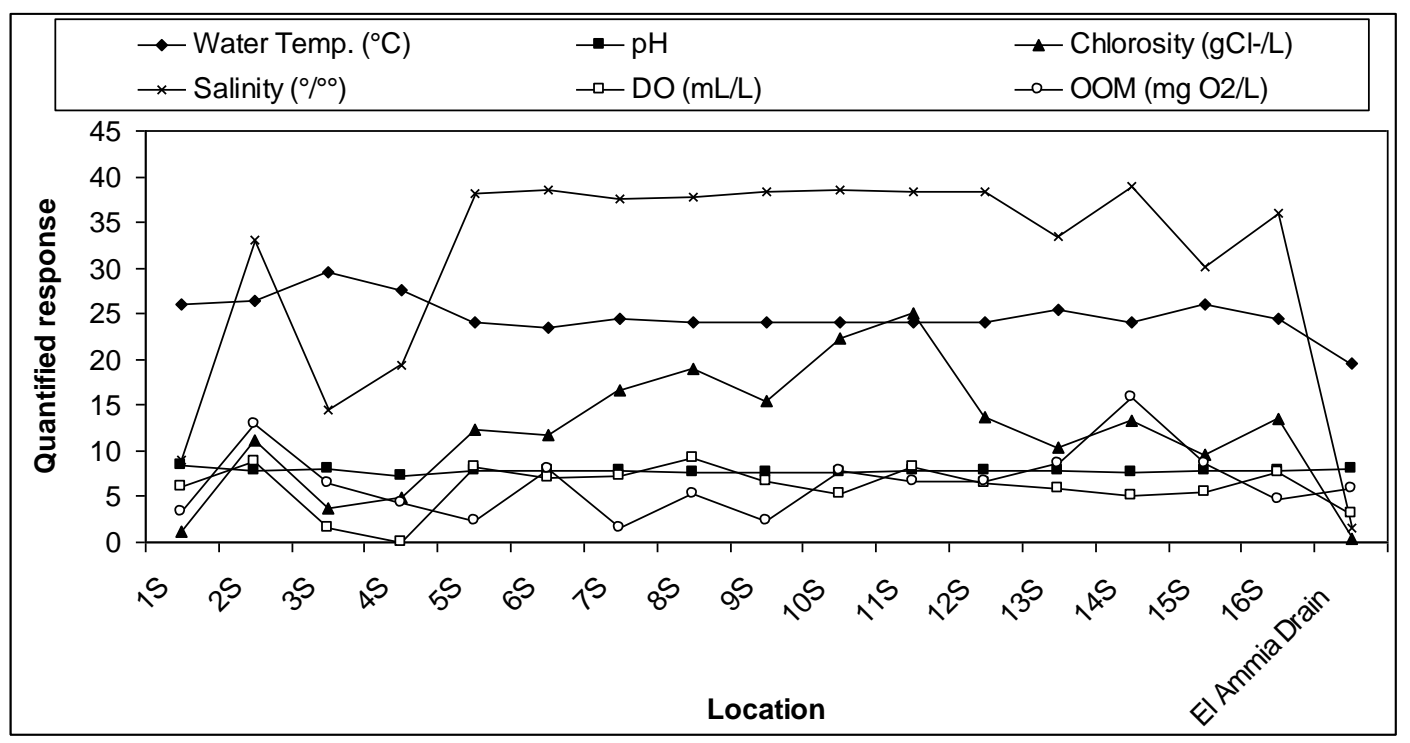

Figure 3: Physicochemical parameters recorded in Abu-Qir Bay and El-Ammia Drain. 


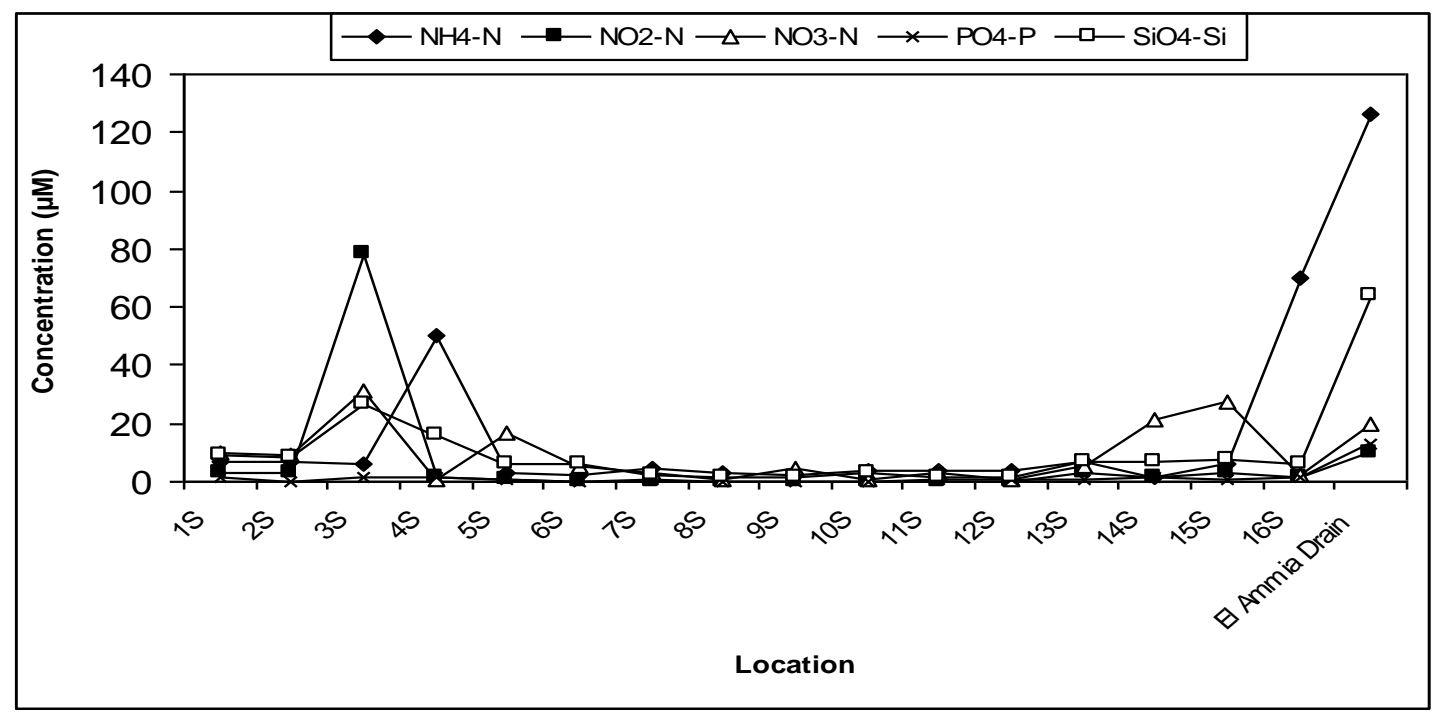

Figure 4: Spatial variation in nutrient salts concentration in Abu-Qir Bay and El-Ammia Drain.

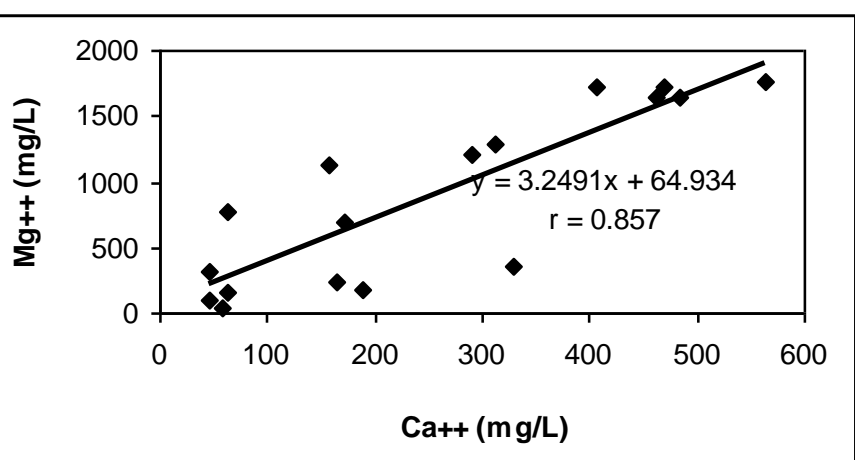

Figure 5: Correlation between calcium and magnesium in Abu-Qir Bay. 


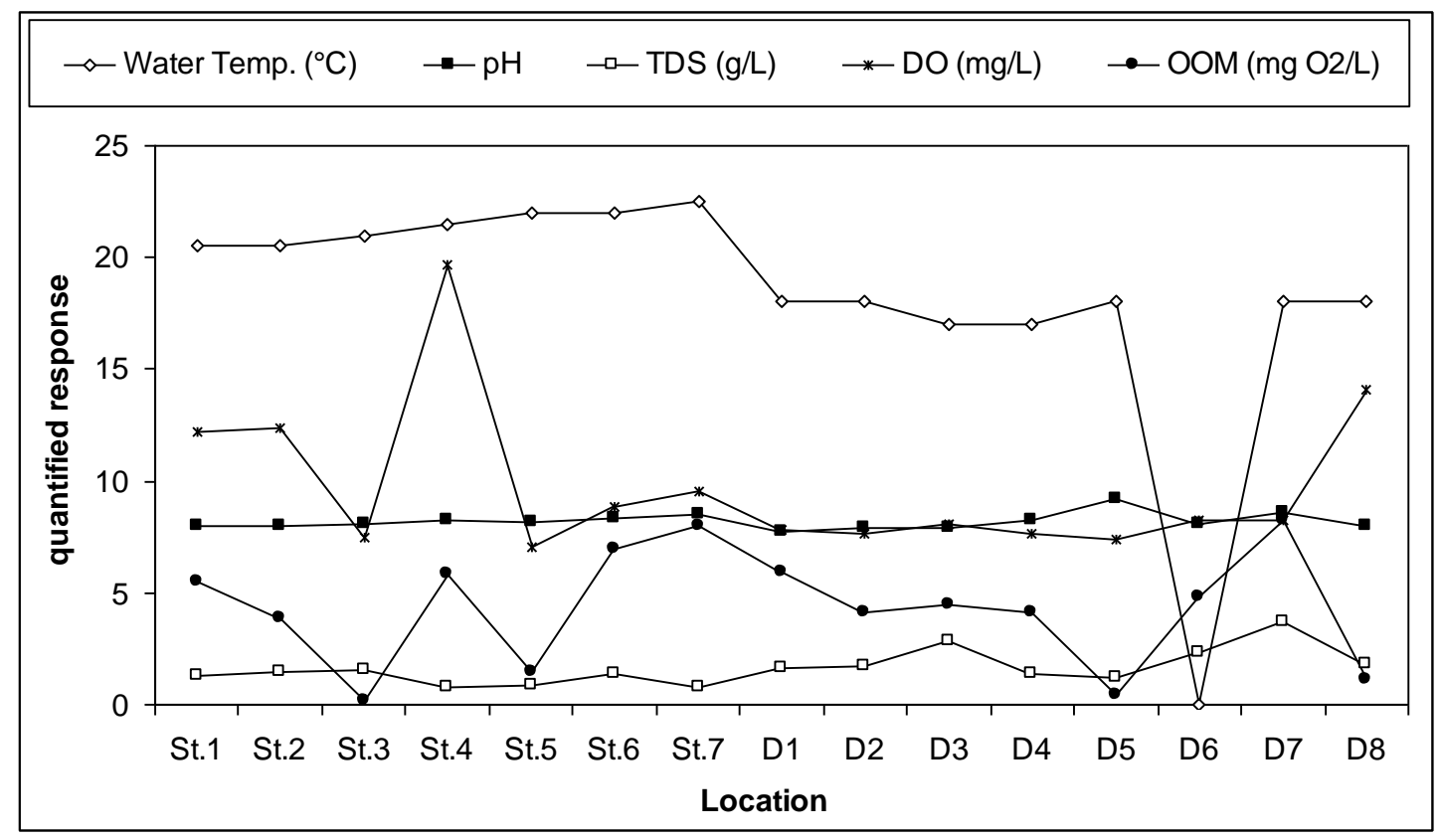

Figure 6: Physicochemical parameters recorded in Lake Edku and its related Drains.

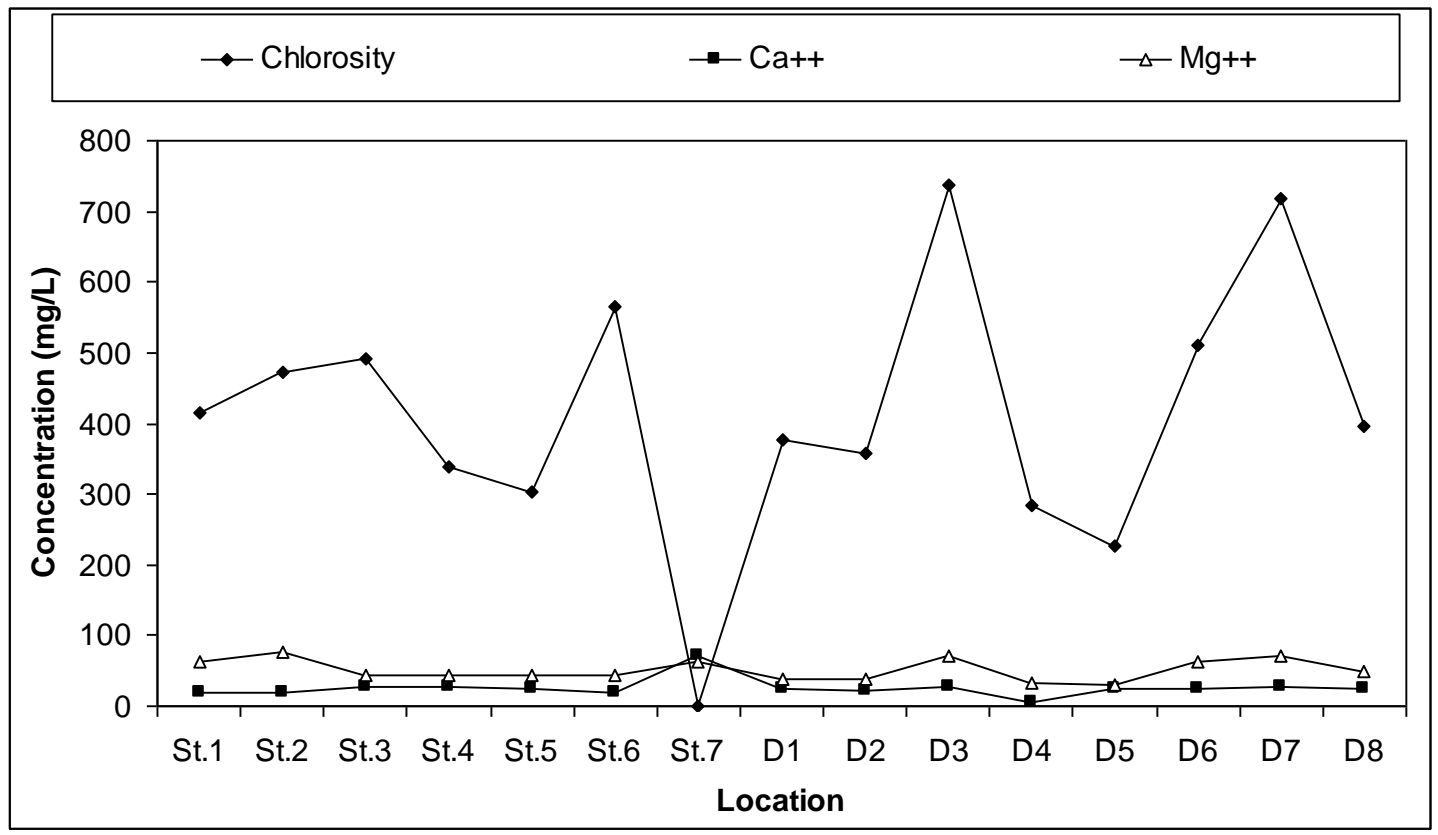

Figure 7: Spatial variation in some major ions concentration in Lake Edku and its related Drains. 


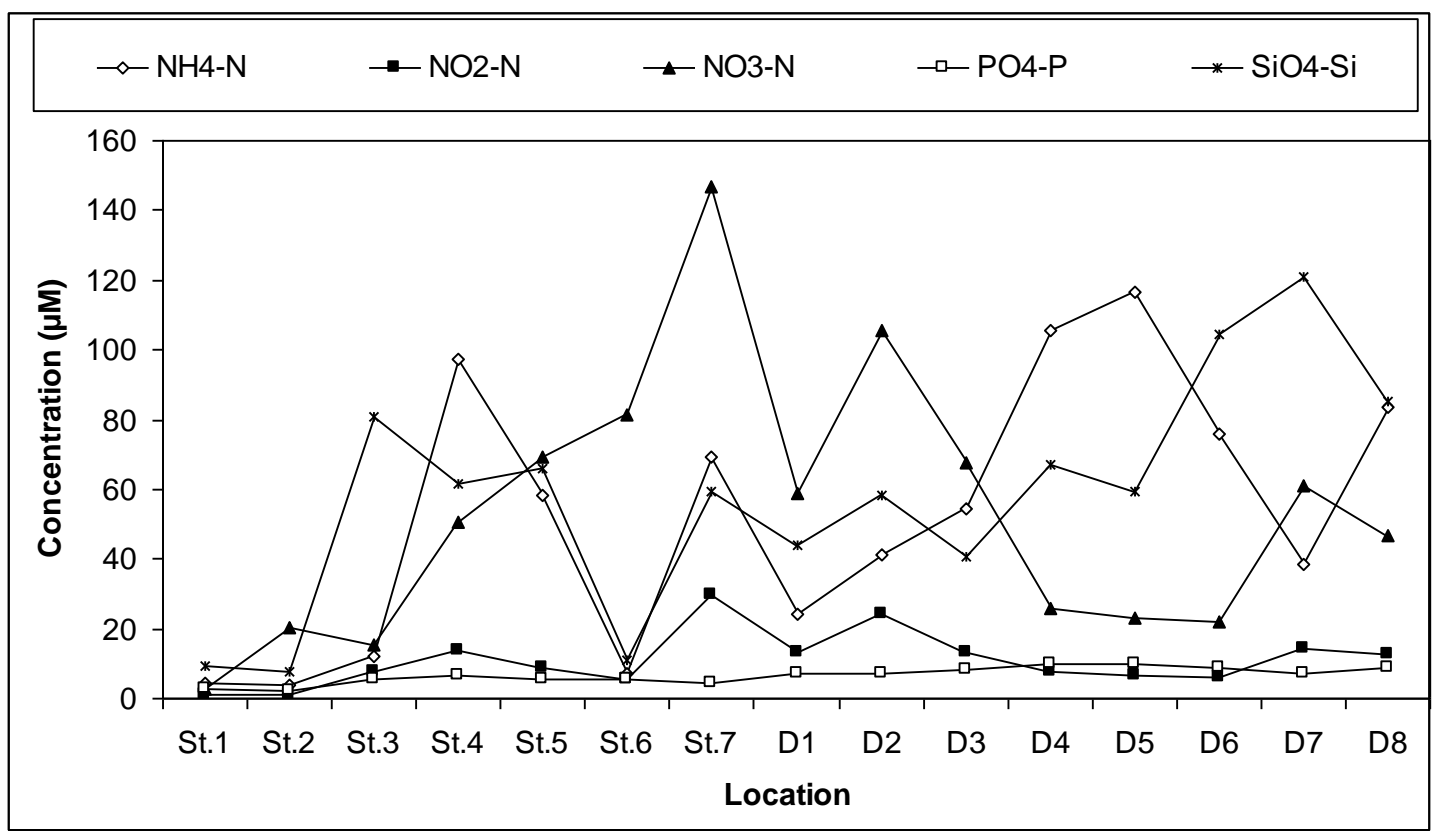

Figure 8: Spatial variation in nutrient salts concentration in Lake Edku and its related Drains.

\section{REFERENCES}

1. El-Deeb MKZ. Hydrography and chemistry of Abu-Qir Bay. M.Sc. Thesis, Fac. Sci., Alex. Univ. 1977. 194.

2. Dowidar NM, Gereges M, El-Samra MI, El-Deek MS. General review of National Institute of Oceanography and Fisheries, A.R.E., 1983; 23: 49-68.

3. Osman MM, Dorgham MM. Environmental conditions in Abu-Qir Bay, East of Alexandria. I-Physico-chemical characteristic and water circulation. Chemosphere. 1987 ;16 [23]: 361-8.

4. El-Gindy $\mathrm{AAH}$. On the dynamic features and the possible mechanism of the vertical mixing in Abu-Qir Bay. Rapp Comm Int Mer Medit. 1988; 31 [2]: 200.

5. Mahmoud ThH, Abdel-Hamied OH. The Distribution and the relationship between nitrogen and phosphorous compounds in Abu-Qir Bay, Alexandria,
Egypt. Bulletin of High Institute of Public Health. 1991; 21 [2]: 361-70.

6. Tayel FTR. The physical and chemical conditions of Abu-Qir Bay waters, Alexantdria, Egypt, Bulletin of High Institute of Public Health.1992;22[1];8799.

7. Nessim RB, El-Deek MS. Eutrophication in Abu-Qir Bay, proc.3 $3^{\text {rd }}$ International Conference "Environment Protection is a must", 13-15 April, Sheraton, Alexandria, 1993. 115-130.

8. Nessim RB, El-Deek MS. The influence of and-based sources on the nutrient level in Abu-Qir Bay, Bulletin of High Institute of Public Health. 1995;25 [1]: 209-20.

9. Fahmy MA. Hydrochemistry and nutrients of Abu-Qir Bay during summer 1995. Bulletin of Faculty of Science, Alexandria University. 1997; 37 [2]: 17186. 
10. Okbah MA, Tayel FTR. Water quality in the coastal area of Alexandria, Bulletin of National Institute of Oceanography and Fisheries, A.R.E. 1999; 25: 89-102.

11. Abdel-Aziz NE, Fahmy, MA, Dorgham MM. Hydrography, nutrients and plankton abundance in the hot spots of Abu-Qir Bay, Alexandria, Egypt. Mediterranean Marine Science. 2001;2 [2]: 17-31.

12. El-Rayis O, El-Sabarouti M, Abdelmoneim $M$, Faragallah, $H$. Association of $P$ with sediments of a Nile Delta Bay. $7^{\text {th }}$ International Conference on the Mediterranean Coastal Environment. MEDCOAST 05.E. öchan [Editor]. 25-29 October-2005 Kusadast. Turkey.

13. Vogel Al. A text book of quantitative inorganic analysis. London: Longman, Green Co; 1966. 1199.

14. Grasshoff K. Methods of seawater analysis. New York: Verlage Chemie. Weinheim; 1976. 317.

15. Carlberg SR. New Belatic Manual, Intern. Coun. For the Explo. of the sea. Cooperative Res. Rep. Series A.N. 29, Copenhagen: 1972.
16. Heron J, Mc Carthy FJH. Journal Theorital and applied Limnology. 1960;7: 39 p.

17. Nessim RB, Masoud MS, Maximous NN. Water characteristics of Alexandria hot spots. Egyptian Journal of Aquatic Research. 2005; 31 [special Issue]: 2537.

18. Radwan AAM. Hydrographic structure and heat budget of Abu Qir Bay. M.Sc. Thesis, Fac. Sci., Alex. Univ. 1996.101.

19. Awad H, Youseff NA. Nile River Delta: Rosseta branch and Edku Lagoon. Accessed at March 12, 2008.

Available from:

htt: //nest.S4.Se/mnode/Africa/Egypt/Nile Delta- Rosseta/Nile -rosettabud.

20. Orive E, Elliott $M$, de Jong VN. [eds]. Nutrients and eutrophication in estuaries and coast water. Hydrobiolgia. 2002; 475/476:1-19. 